\title{
Factors affecting bovine corneal endothelial cell density in vitro
}

\author{
E W Johnstone, H C Wong, D J Coster, K A Williams
}

\begin{abstract}
Aims-To examine factors influencing the density and contact inhibition of bovine corneal endothelial cells cultured in vitro. Methods-Cell counts were performed on bovine corneal endothelial cells cultured for various times in the presence of $10 \%$ fetal calf serum, with or without varying concentrations of growth factors, $5 \%$ dextran T-500, or $2 \%$ chondroitin sulphate, at $32^{\circ} \mathrm{C}$ or $37^{\circ} \mathrm{C}$, and after treatment with $\beta$ galactosidase.

Results-Both basic fibroblast growth factor (FGFb) and retinal crude extract (RCE), but neither epidermal growth factor (EGF) nor acidic fibroblast growth factor (FGFa), increased endothelial cell density in vitro $(p<0 \cdot 05)$. Continuous exposure to RCE resulted in a higher cell density than did a 24 hour pulse $(\mathbf{p}<0 \cdot 01)$, and higher cell densities were achieved at $37^{\circ} \mathrm{C}$ than at $32^{\circ} \mathrm{C}(\mathbf{p}<0.0001)$. In the absence of RCE, dextran T-500 increased cell density modestly $(p<0.05)$; in the presence of RCE, the addition of dextran $T-500$ had no effect on final cell density, whereas chondroitin sulphate significantly decreased final cell density $(p<0 \cdot 01)$. In the absence of exogenous growth factors, $\beta$ galactosidase treatment resulted in a $50 \%$ increase in final cell density compared with controls $(p<0 \cdot 0001)$. Conclusions-Bovine corneal endothelial cell growth can be augmented under conditions different from those used in corneal preservation systems. The final cell density in a confluent monolayer can be increased by treatment with $\beta$ galactosidase, suggesting that corneal endothelial cells may be contact inhibited through a $\beta$ galactosidase sensitive receptor system.
\end{abstract}

(Brf Ophthalmol 1996; 80: 256-262)

Department of Ophthalmology, Flinders University of South Australia, Adelaide, South Australia, Australia E W Johnstone $\mathrm{H}$ C Wong D J Coster $\mathrm{K}$ A Williams

Correspondence to: Dr K A Williams, Department of Ophthalmology, Flinders Mphthalmology, Flinders Park, SA 5042, Australia. Park, SA 5042, Australia. 30 November 1995
Donor corneas invariably exhibit a degree of storage associated endothelial cell damage and it would be useful to initiate corneal endothelial cell replication by appropriate in vitro manipulations, before transplantation. Extracellular matrix components and soluble growth factors have been observed to influence the replication of corneal endothelium in vitro, ${ }^{1-4}$ and growth factors have been used to promote epithelial and endothelial cell mitosis and corneal wound repair. . $^{5-7}$

The stimulatory effects of growth factors have usually been examined at $37^{\circ} \mathrm{C}$ in well defined serum free medium or medium containing very low levels of fetal calf serum
(FCS). Components such as colloidal osmotic agents that are frequently added to corneal storage media are generally absent. In eye banks, donor corneas are usually stored at $4^{\circ} \mathrm{C}$ or $31-34^{\circ} \mathrm{C}$, depending upon the type of medium employed. Media designed for corneal storage at $4^{\circ} \mathrm{C}$ contain colloidal osmotic agents, whereas media used at $31-34^{\circ} \mathrm{C}$ contain both colloidal osmotic agents and FCS. ${ }^{8}$

Human corneal endothelium may fail to undergo mitosis in vivo because essential growth factors may be locally absent within the microenvironment of the corneal endothelial cell. However, contact inhibition may also reduce the likelihood of endothelial cell division. The molecules responsible for control of contact inhibition are probably membrane bound glycoproteins possessing a terminal $\beta$ glycosidically linked galactose that is critical for growth inhibition..$^{9-12}$ It has previously been demonstrated that the culture of human fibroblasts in the presence of $\beta$ galactosidase increases cell proliferation rates and results in a twofold higher final cell density. ${ }^{13}$

In this study, we examined the effects of factors with the potential to influence corneal endothelial cell density. In particular, we investigated the effect of addition of growth factors and colloidal osmotic agents and the influence of incubation temperature and $\beta$ galactosidase treatment on the density of bovine corneal endothelial cells grown in vitro as monolayer cultures in FCS supplemented RPMI 1640 medium. The goal was to identify conditions under which corneal endothelial cell density might be increased in preconfluent and confluent cultures and to examine the role, if any, of contact inhibition in influencing cell density.

\section{Materials and methods}

ISOLATION AND CULTURE OF BOVINE CORNEAL ENDOTHELIAL CELLS

Bovine eyes were obtained from local abattoirs. Eyes were immersed for 5 minutes in povidone iodine (Johnson and Johnson, North Ryde, NSW, Australia) and rinsed three times in $0.9 \%$ weight/volume (w/v) normal saline. Corneas were dissected from the globes $2 \mathrm{~mm}$ anteriorly of the limbus. Each cornea was placed epithelial-side down and HEPES RPMI 1640 medium (ICN Biochemicals, Seven Hills, NSW, Australia) supplemented with $10 \%$ volume/volume (v/v) FCS, 2 mM L-glutamine, $100 \mathrm{units} / \mathrm{ml}$ penicillin, and $100 \mu \mathrm{g} / \mathrm{ml}$ streptomycin sulphate, hereafter referred to as HRPMI-10\%, was placed into the corneal cup. Corneal endothelium was removed using a 
gentle scraping action with an olive tipped spatula. The suspension containing corneal endothelial cells was passed several times through the orifice of a pasteur pipette to break up cell sheets. Isolated cells from five corneas were then cultured in a $25 \mathrm{~cm}^{2}$ flask (Costar, Cambridge, MA, USA) in HRPMI-10\%. Culture medium was replaced weekly. Cell purity was assessed at the microscope: endothelial cells were identified on the basis of their distinctive 'cobblestone' appearance. Multiple separate isolations were performed. Endothelial cells were always used at the first subculture after the primary isolation.

SURFACE COATING OF CLUSTER PLATES Cluster plates (Costar, Cambridge, MA, USA) were incubated with $0.005 \% \mathrm{w} / \mathrm{v}$ human placental acid soluble collagen type IV (Sigma Chemical Company, St Louis, MO, USA) in $0 \cdot 1 \mathrm{M}$ acetic acid for $2-3$ hours at $32^{\circ} \mathrm{C}$. The coating solution was then aseptically removed and the cluster plates were dried overnight.

\section{MEASUREMENT OF ENDOTHELIAL CELL DENSITY}

Bovine endothelial cells $\left(2 \times 10^{4} /\right.$ well $)$ were seeded on to collagen coated 25 well plates. Cells were then cultured under varying conditions depending on the experiment, using HRPMI-10\%. For investigations on the effect of growth factors on endothelial cell density, non-confluent cultures were used. For all other experiments, confluent cultures were used. Cells were harvested from wells by trypsin digestion and counted in a haemocytometer. Viability was assessed by trypan blue staining. The cell counts were converted to viable cells $/ \mathrm{mm}^{2}$ based on culture vessel surface area. Mean cells $/ \mathrm{mm}^{2}$ plus or minus 1 standard deviation (SD) were calculated from four to five replicate wells.

GROWTH FACTORS

Murine submaxillary gland epidermal growth factor (EGF) was obtained from Sigma Chemical Co, St Louis, MO, USA. Bovine brain acidic fibroblast growth factor (FGFa) and human recombinant basic fibroblast growth factor (FGFb) were obtained from Boehringer Mannheim GmbH (Mannheim, Germany). A crude extract of retina was prepared from retinas harvested from bovine eyes removed within 8 hours of death. Retinas were placed in Dulbecco's A phosphate buffered saline supplemented with $0.2 \% \mathrm{w} / \mathrm{v}$ glucose ( $1 \mathrm{ml} /$ retina), incubated at room temperature for 2 hours and centrifuged at $400 \mathrm{~g}$ for 10 minutes. The supernatant retinal crude extract (RCE) was removed and stored in aliquots at $-80^{\circ} \mathrm{C}$. RCE was filtered through a $0.22 \mu \mathrm{m}$ filter immediately before use.

EFFECTS OF GROWTH FACTORS ON CELL DENSITY

The experiments on the influence of growth factors on endothelial cell density were performed on preconfluent cultures. Cells were incubated for 7 days at $37^{\circ} \mathrm{C}$ in supplemented HRPMI-10\%, before the addition of growth factors. Concentrations of growth factors were chosen to span ranges that had previously been found to induce mitosis of corneal endothelial cells in vitro. ${ }^{37}$ Cells were then incubated with growth factors for a further 7 days, at which time the number of viable cells/well was determined as a measure of density.

ANALYSIS OF INCUBATION TEMPERATURE ON CELL DENSITY

Bovine corneal endothelial cells were grown in 24 well plates (Costar, Cambridge, MA, USA) using HRPMI-10\% until cells were confluent. Fresh HRPMI-10\% was then added to one third of the wells. RCE supplemented HRPMI-10\% (40 $\mu \mathrm{l} \mathrm{RCE} / \mathrm{ml})$ was added to a further one third of wells for 24 hours only, after which the medium was replaced with HRPMI-10\%. RCE supplemented HRPMI$10 \%$ was added to the final one third of wells for the entire experiment. Medium was replaced weekly. Plates were set up in duplicate: one plate was incubated at $32^{\circ} \mathrm{C}$ and the second plate at $37^{\circ} \mathrm{C}$. The plates were then incubated for 25 days before cell densities were determined.

\section{ANALYSIS OF COLLOIDAL OSMOTIC AGENTS ON} CELL DENSITY

Bovine corneal endothelial cells were grown in 24 well plates (Costar, Cambridge, MA, USA) in HRPMI-10\% until they reached confluency. One third of wells was supplemented with $2 \%$ w/v shark/whale chondroitin sulphate grade 3 (Sigma Chemical Company, St Louis, MO, USA). One third was supplemented with $5 \%$ w/v dextran T-500 (Pharmacia, Uppsala, Sweden). The final one third received unsupplemented medium. Half of each group also received RCE $(40 \mu \mathrm{l} / \mathrm{ml})$. Cell densities were determined after incubation for 7 days at $37^{\circ} \mathrm{C}$.

\section{TREATMENT WITH $\beta$ GALACTOSIDASE}

After bovine corneal endothelial cell cultures had reached confluency in HRPMI-10\%, the medium was replaced and half of the wells were supplemented with $40 \mu 1 / \mathrm{ml}$ retinal crude extract. The medium was replaced 24 hours later with $200 \mu \mathrm{l}$ of fresh serum free HRPMI. The enzyme $\beta$ galactosidase (Escherichia coli grade VIII, Sigma Chemical Co, St Louis, MO, USA) at $3 \cdot 2$ units/well was added to half of the wells previously either treated or untreated with RCE. Cultures were incubated for $6.5-8$ hours at $37^{\circ} \mathrm{C}$, after which the medium was replaced with fresh HRPMI$10 \%$. Cell density was determined after incubation for 7 days at $37^{\circ} \mathrm{C}$. 
analysed together by three way analysis of variance, the variables being temperature of incubation, exposure to RCE and the individual experiment, or exposure to colloidal osmotic agent, exposure to RCE and the individual experiment, depending on which variables were being tested. Once a treatment was found to be significant, internal significance was determined by the Newman-Keuls multiple range test. ${ }^{14}$

\section{Results}

\section{INFLUENCE OF GROWTH FACTORS ON CELI DENSITY}

The influence of RCE, EGF, FGFa, and $\mathrm{FGFb}$ on the growth of bovine corneal endothelial cells is shown in Figure 1. Because preliminary experiments had demonstrated that higher cell densities were achieved on plates coated with collagen type IV rather than on gelatin or on uncoated plates (data not shown), all experiments were performed with collagen coated plates. Of cells initially seeded into each well, 10-16\% had attached at 24 hours; unattached cells were washed away when the medium was changed.

RCE at concentrations of $20-80 \mu \mathrm{l} / \mathrm{ml}$ induced significantly higher cell densities (measured by cells $/ \mathrm{mm}^{2}$ ) than were found in control wells without RCE $(p<0.05)$; RCE at $40 \mu \mathrm{l} / \mathrm{ml}$ was used thereafter as a positive control in all experiments $(p<0.01$ compared with negative controls). RCE produced no visible changes in endothelial cell morphology at any concentration examined.

Neither EGF (0-50 ng/ml) nor FGFa (0-50 $\mathrm{ng} / \mathrm{ml}$ ) had any significant effect on final cell density in the presence of $10 \%$ FCS (Fig 1), $\mathrm{p}>0.05$, although EGF did induce fibroblastic morphological changes in endothelial cells at

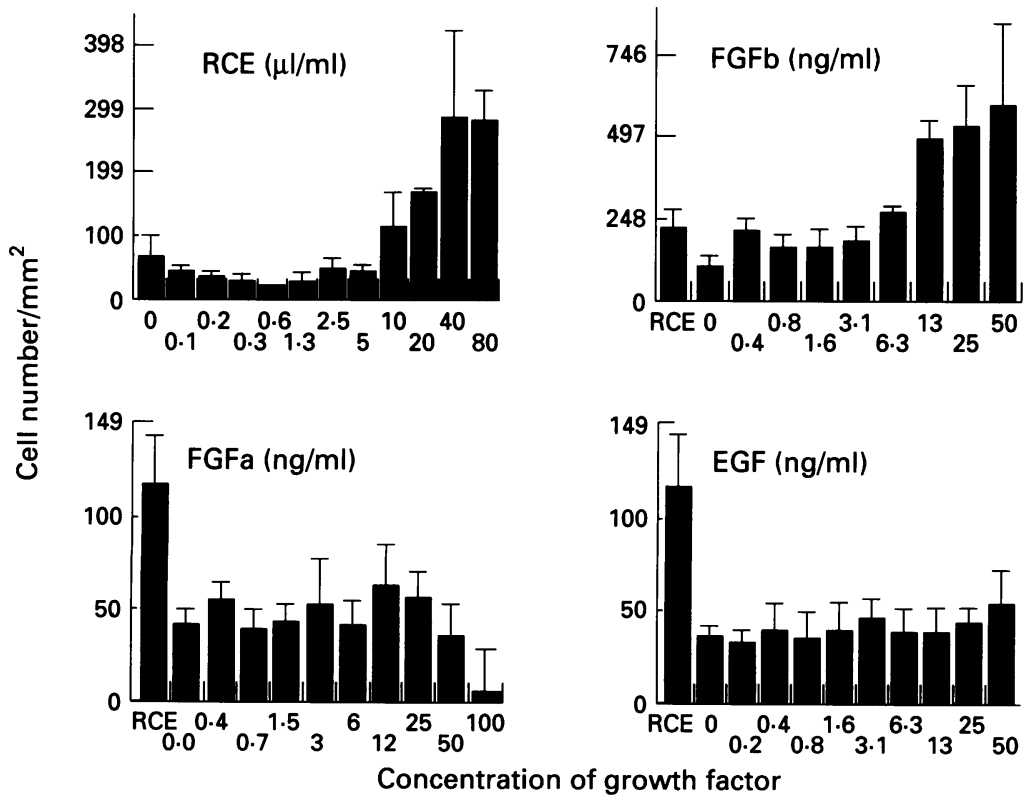

Figure 1 Bovine corneal endothelial cell density (cells $/ \mathrm{mm}^{2}$ ) after culture for 7 days at $37^{\circ} \mathrm{C}$ with different concentrations of $R C E$ (representative of three experiments), $F G F b$ (representative of three experiments), FGFa (representative of three experiments), and EGF (representative of two experiments). RCE at $40 \mu \mathrm{l} / \mathrm{ml}$ was used as positive control for titrations of FGFb, FGFa, and EGF. Error bars signify plus or minus 1 standard deviation. concentrations above $10 \mathrm{ng} / \mathrm{ml}$. Cell confluency was not achieved in these cultures over the time frame of the experiment, with cell densities always less than 75 cells $/ \mathrm{mm}^{2}$. In contrast, FGFb consistently induced cell densities that were significantly higher than those in control wells $(p<0.05)$. However, cells grown in medium supplemented with FGFb at concentrations of greater than $25 \mathrm{ng} / \mathrm{ml}$ often developed a fibroblastic appearance (Fig 2). The pooled cell density data from all titration experiments using FGFb were separated into two groups: one composed of values from wells that received $\mathrm{FGFb}$ at concentrations that did not induce morphological changes $(\leqslant 25 \mathrm{ng} / \mathrm{ml})$, and the second of values from wells that received $\mathrm{FGFb}$ at concentrations that did result in morphological changes $(>25 \mathrm{ng} / \mathrm{ml})$. FGFb concentrations of $\leqslant 25$ $\mathrm{ng} / \mathrm{ml}$ resulted in cell densities that were not significantly different from the densities obtained in the absence of growth factor $(p>0.05)$. There was no significant difference $(p>0.05)$ in the percentage increase in cell densities achieved between the RCE group $(40 \mu \mathrm{l} / \mathrm{ml})$ and the $>25 \mathrm{ng} / \mathrm{ml} \mathrm{FGFb}$ group.

EFFECT OF DURATION OF EXPOSURE TO RCE A 35 day time course experiment was performed, to investigate the effect of continuous exposure to RCE compared with a 24 hour pulsed exposure (Fig 3). Endothelial cell density reached a peak at 10-15 days, irrespective of whether RCE was present or absent. However, cultures continuously exposed to RCE peaked at cell densities (mean cell density $(\mathrm{SD})=547(184)$ cells $/ \mathrm{mm}^{2}$ ) that were significantly higher than the levels reached by cultures pulsed with RCE for the first 24 hours only (mean cell density $(\mathrm{SD})=288 \quad(114)$ cells $/ \mathrm{mm}^{2}$ ) or the levels in the negative control cultures (mean cell density $(\mathrm{SD})=104$ (65) cells $\left./ \mathrm{mm}^{2}\right), \mathrm{p}<0 \cdot 01$.

\section{INTERACTION BETWEEN TEMPERATURE AND}

DURATION OF EXPOSURE TO RCE

Cultures were exposed for the first 24 hours only, or continuously exposed to RCE over 25 days (twice as long as was required for cell densities to peak in the previous experiment) at either $32^{\circ} \mathrm{C}$ or $37^{\circ} \mathrm{C}$ (Fig 4). Control cultures were not exposed to RCE. Both duration of exposure to RCE and the temperature of incubation significantly influenced final cell density $(\mathrm{p}<0.01$ and $\mathrm{p}<0.0001$, respectively), but there was no interaction between the two variables $(p=0 \cdot 12)$. Specifically, incubation at $37^{\circ} \mathrm{C}$ resulted in a significant increase in cell density compared with incubation at $32^{\circ} \mathrm{C}$, independent of RCE exposure time $(\mathrm{p}<0.0001)$. When data from all experiments $(n=5)$ were pooled, pulsed treatment with RCE produced higher cell densities (24\% increase at $32^{\circ} \mathrm{C} ; 36 \%$ increase at $37^{\circ} \mathrm{C}$ ) than were obtained in the respective control wells $(p<0.01$ for each temperature). Likewise continuous exposure to RCE resulted in higher cell densities again $\left(95 \%\right.$ increase at $32^{\circ} \mathrm{C}$; 


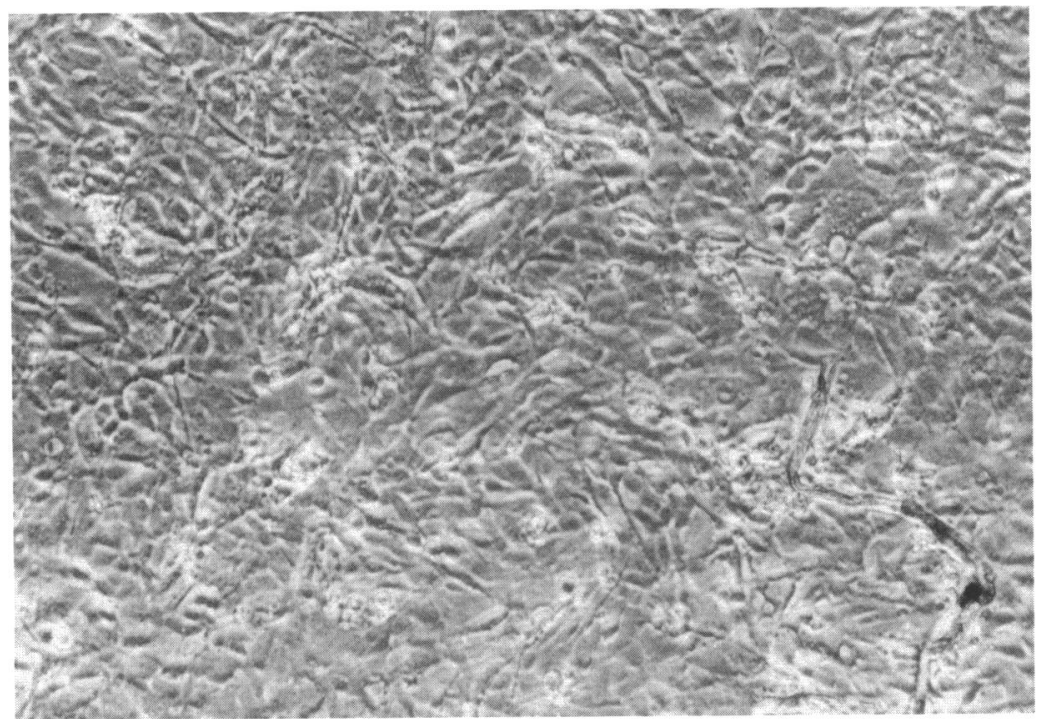

Fig $2 A$

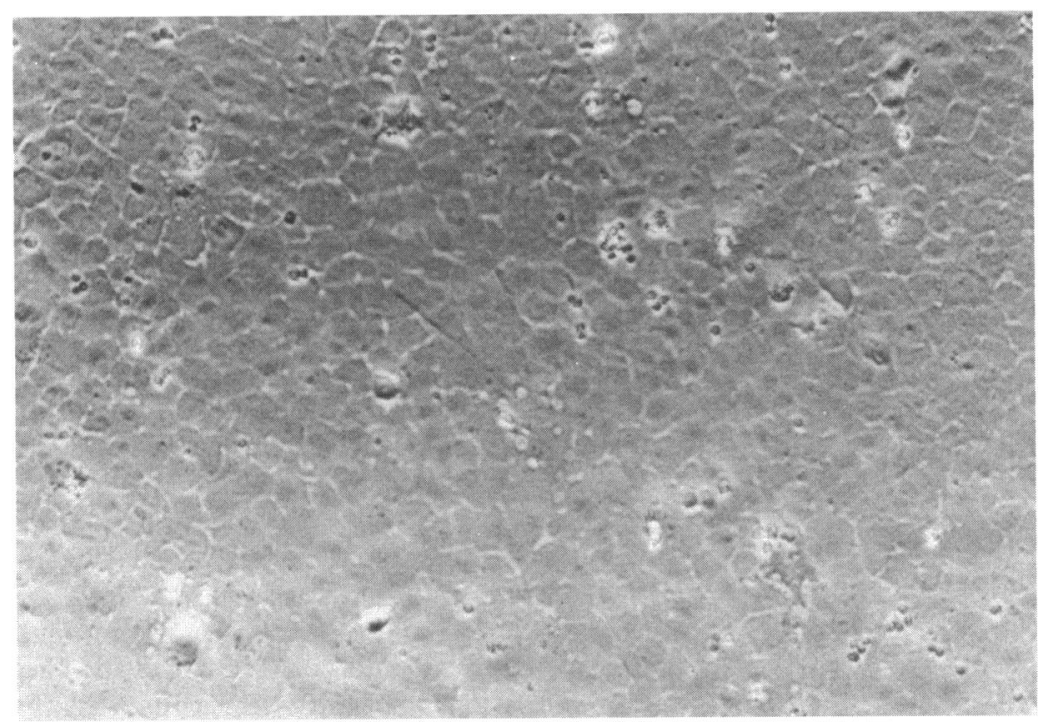

Fig $2 B$

Figure 2 Morphology of bovine corneal endothelial cells grown $(A)$ in the presence of $25 \mathrm{ng} / \mathrm{ml} \mathrm{FGFb}$, or $(B)$ in the presence of $40 \mu \mathrm{l} / \mathrm{ml}$ of RCE. Fibroblastic changes are apparent in $(A)$, whereas the cells in $(B)$ have a normal appearance.

Magnification $\times 510$.
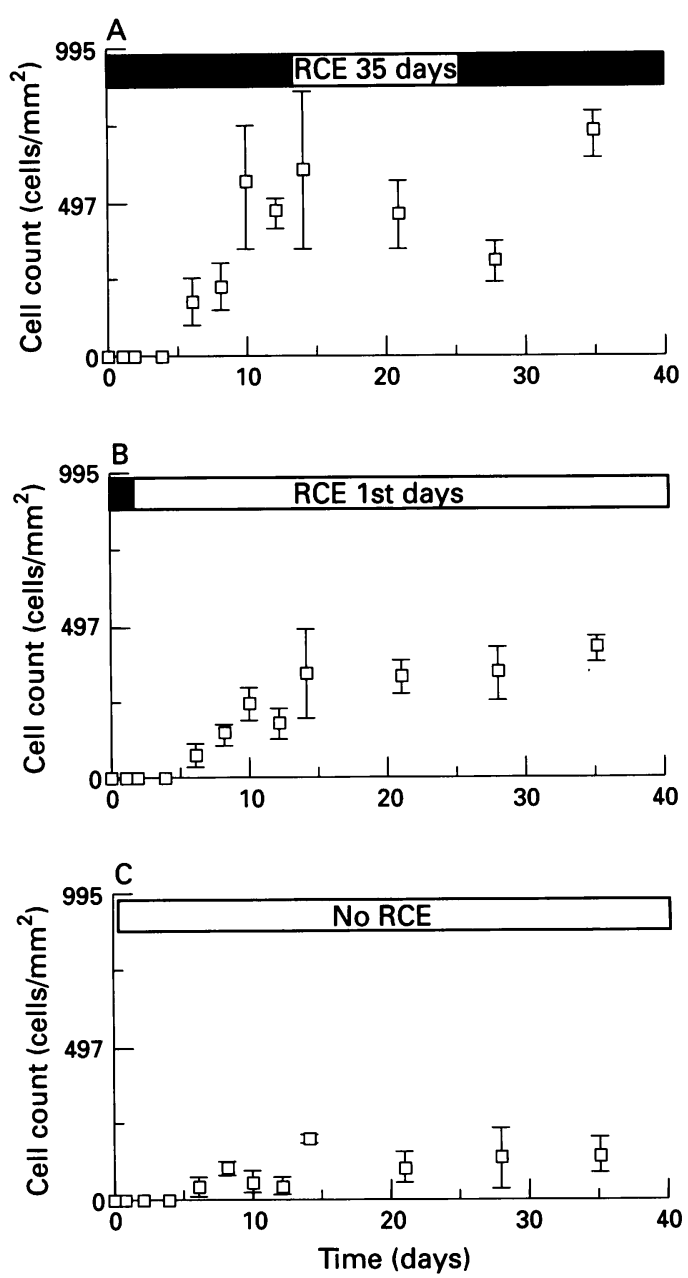

Figure 3 Effect of duration of exposure to RCE. Bovine corneal endothelial cells were cultured for 0-35 days at $37^{\circ} \mathrm{C}$. RCE $(40 \mu \mathrm{lml})$ was present: $(A)$ continuously, (B) for 24 hours at the outset only, or (C) never. Error bars signify plus or minus 1 standard deviation.

$\mathrm{T}-500$ resulted in a modest increase in final cell density compared with cultures where either no colloidal osmotic agent was added $(21 \%$ increase, $\mathrm{p}<0.05)$ or chondroitin sulphate was added $(31 \%$ increase, $\mathrm{p}<0.01)$.

In the presence of RCE, final cell densities

$79 \%$ increase at $37^{\circ} \mathrm{C}$ ), and these were statistically significantly different from both the control $(p<0.01)$ and the RCE pulsed $(p<0.01)$ treatment groups.

\section{EFFECT OF COLLOIDAL OSMOTIC AGENTS ON CELL DENSITY}

Cultures of corneal bovine endothelium were incubated in HRPMI-10\% supplemented with $5 \%(w / v)$ dextran $\mathrm{T}-500$ or $2 \%(\mathrm{w} / \mathrm{v})$ chondroitin sulphate. Analysis of all experiments (Fig 5) showed that the choice of osmotic agent had a significant effect on final cell density $(p<0.0001)$. A significant interaction was also observed between the colloidal osmotic agents and RCE ( $p=0.005)$. When no RCE was added, final cell densities were dependent on the colloidal osmotic agent to a lesser extent than when RCE was present. In the absence of RCE, the addition of chondroitin sulphate to the medium had no significant effect on the final cell density, compared with controls, whereas the addition of dextran were also dependent upon the colloidal osmotic agent. The addition of dextran T-500 to the medium resulted in no significant difference in final cell density compared with cultures to which no colloidal osmotic agent was added $(p>0.05)$. However, the addition of chondroitin sulphate resulted in a significant decrease in final cell density, compared with cultures where either no colloidal osmotic agent was added $(45 \%$ decrease, $\mathrm{p}<0.01)$ or dextran T-500 was added (40\% decrease, $\mathrm{p}<0 \cdot 01$ ).

TREATMENT OF CORNEAL ENDOTHELIAL CELLS WITH $\beta$ GALACTOSIDASE

Results from five experiments in which confluent corneal endothelial cultures were treated with $\beta$ galactosidase, with or without RCE, were analysed (Fig 6). In the absence of RCE, $\beta$ galactosidase treatment resulted in a $50 \%$ increase in final cell density $(\mathrm{p}<0.0001)$. In the presence of RCE, enzyme treatment did not increase cell density significantly compared 


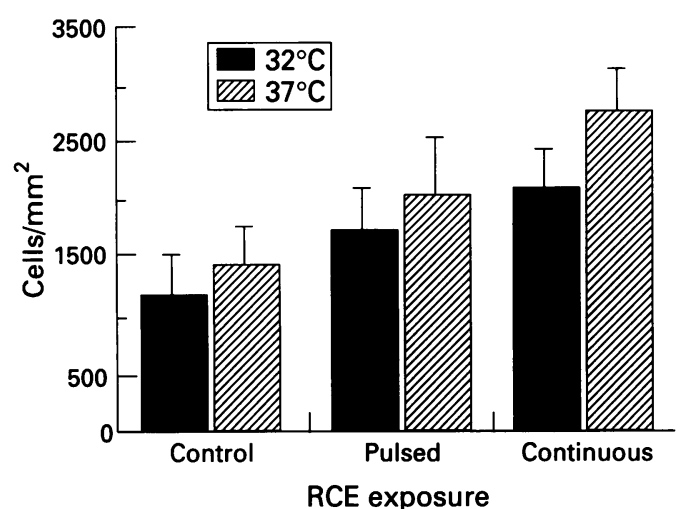

Figure 4 Effect of temperature of incubation and the duration of exposure to RCE on cultured bovine endothelial cell density. Cells were never exposed to RCE ('control'), exposed for 24 hours only ('pulsed'), or exposed continuously ('continuous'). Data are representative of five experiments. Error bars signify plus or minus 1 standard deviation.

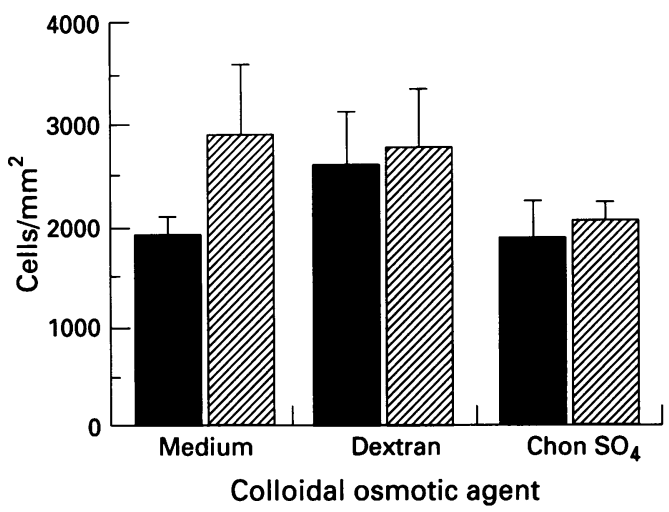

Figure 5 Effect of $5 \%$ w/v dextran T-500 (dextran), 2\% w/v chondroitin sulphate (Chon $\mathrm{SO}_{4}$ ), or medium without colloidal osmotic agent (medium) on bovine corneal endothelial cell density at 7 days, in the absence (solid bars) or presence (hatched bars) of RCE. Data are representative of five experiments. Error bars signify plus or minus 1 standard deviation.

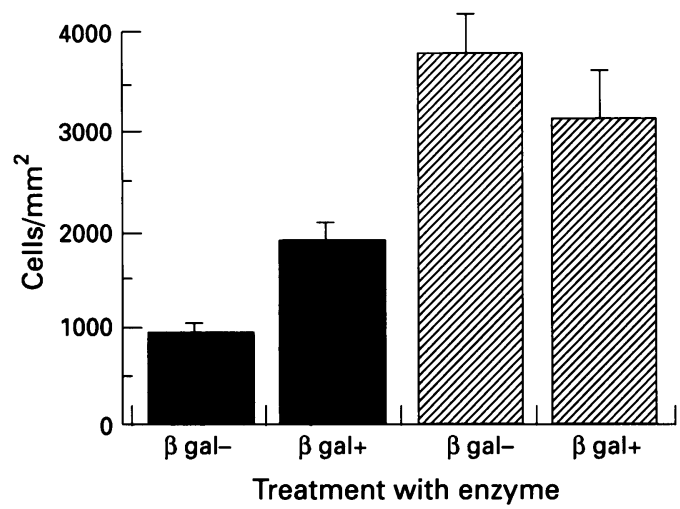

Figure 6 Bovine corneal endothelial density following exposure to $\beta$ galactosidase and/or retinal crude extract. Corneal endothelial cells were incubated in the absence or presence of RCE (solid or hatched bars, respectively) to a state of confluency. Half the cultures were treated with $\beta$ galactosidase (' $\beta$ gal + '), whereas the others were untreated $($ ( $\beta$ gal - '). Data are representative of five experiments. Error bars signify plus or minus 1 standard deviation.

with untreated controls: the effects of RCE and $\beta$ galactosidase were not additive $(p=0 \cdot 21)$.

\section{Discussion}

Our aim was to investigate the inter-relationships among factors affecting the growth of bovine corneal cells in vitro. FGFb and EGF were selected for study because both have been shown to stimulate DNA synthesis in bovine corneal endothelial cells in vitro. ${ }^{15}$ EGF has also been demonstrated to stimulate human corneal endothelial cell mitosis ${ }^{16}$ and is used as an additive in some corneal storage media. ${ }^{17}$ FGFa was not expected to affect endothelial cell density and was selected as a negative control. RCE, a well established general cell growth promoting agent, ${ }^{18} 19$ was initially chosen as a positive control. Chondroitin sulphate, dextran T500, and FCS in differing combinations and at varying concentrations are components of currently formulated corneal storage media. Because we were interested in maximising the rate of cell growth, we incubated cultures at $32^{\circ} \mathrm{C}$ (the temperature commonly used for organ culture of human donor corneas) and also at $37^{\circ} \mathrm{C}$. The latter was chosen in the knowledge that human, cat, and bovine corneal endothelial cells survive at least short term culture at this temperature ${ }^{15} 16$ and on the premise that cell growth might be enhanced. Cells were treated with $\beta$ galactosidase in an attempt to circumvent contact inhibition.

Our main findings were, firstly, that both human recombinant $F G F b$ and RCE but neither EGF nor FGFa produced significant increases in bovine endothelial cell numbers over the experimental time frame when added to preconfluent cultures incubated in serum containing medium. $\mathrm{FGFb}$ is reportedly active at concentrations of $0.1 \mathrm{ng} / \mathrm{ml}$ and is maximally effective at $100 \mathrm{ng} / \mathrm{ml}^{3}$ We observed mitogenic activity at concentrations above 25 $\mathrm{ng} / \mathrm{ml}$, but these concentrations also produced unwanted morphological changes that were not observed with active concentrations of RCE. Secondly, exposure of confluent endothelial cell cultures to RCE for even relatively short periods increased cell density, although the effect was more marked as exposure time lengthened. The use of confluent cultures in these experiments was designed to mimic the situation of a damaged corneal endothelium, in which large, irregular cells are, none the less, present in an intact monolayer. Thirdly, in the presence of active concentrations of growth factors, endothelial cell density was always greater at $37^{\circ} \mathrm{C}$ than at $32^{\circ} \mathrm{C}$. Fourthly, whereas dextran T-500 appeared stimulatory for corneal endothelial cells in the absence of RCE and had no particular effect in its presence, chondroitin sulphate actually appeared inhibitory in the presence of RCE. Finally, achievement of higher endothelial cell densities after a brief treatment with the enzyme $\beta$ galactosidase suggested that contact inhibition was mediated through a $\beta$ galactosidase sensitive linkage.

Neither EGF nor FGFa increased corneal endothelial cell densities in FCS containing cultures. Confluency was not achieved over the duration of these experiments, indicating that any potential mitogenic stimulus was not being confounded by the attainment of contact inhibition. Considering the existing literature in which EGF has been shown to promote wound healing, ${ }^{1516}$ these results were somewhat unexpected. EGF has previously been shown to be active at $0.01 \mathrm{ng} / \mathrm{ml}$ and saturable at 
$10 \mathrm{ng} / \mathrm{ml}^{3}$ In retrospect, we cannot be certain that EGF was active in our experiments. However, at levels above $10 \mathrm{ng} / \mathrm{ml}$, it induced the morphological changes towards spindleshaped cells described by others. ${ }^{20}$ It is unlikely that serum concentrations of EGF masked effects on cell density in our experiments. The normal concentration of EGF in adult serum is about $700 \mathrm{pg} / \mathrm{ml}^{21}$ The EGF in the $10 \% \mathrm{FCS}$ used to supplement the medium in our experiments might thus have contributed an additional $0.07 \mathrm{ng} / \mathrm{ml}$ to the exogenous levels we employed. Even so, this concentration was not high enough to induced morphological changes in control cultures. Existing evidence suggests that EGF acts synergistically with an unknown factor (or factors) present in serum. ${ }^{16}$ We cannot exclude the possibility that our serum source was deficient in an unknown mitogenic factor, and that the EGF was able to affect cell morphology in the absence of this factor, but unable to drive cell division. Little information is available from other sources on the effects of FGFa on corneal endothelial cell density.

RCE was the most effective growth promoting substance studied. The longer that cells were cultured with RCE, the greater the cell densities that were obtained, but even treatment for 24 hours induced a significant effect. Because Sperling and his co-workers have demonstrated that more damage is induced to the endothelia of whole human corneas incubated at $37^{\circ} \mathrm{C}$ than at temperatures at (or below) $34^{\circ} \mathrm{C}, 22$ temperatures in the standard organ culture systems used for the preservation of human corneas are $31-34^{\circ} \mathrm{C}$. Although greater endothelial cell densities were obtained when cultures were incubated at $37^{\circ} \mathrm{C}$ than at $32^{\circ} \mathrm{C}$, a positive (albeit weak) effect was still noted at $32^{\circ} \mathrm{C}$.

Colloidal osmotic agents are often incorporated into corneal storage media to control corneal hydration. The effects of these agents on the endothelium of undamaged corneas have been investigated previously. ${ }^{823-26}$ Because corneal endothelial cells take up dextran T-500 into cytoplasmic vacuoles, ${ }^{23}$ we considered that this substance might interfere with cellular events such as mitosis. However, dextran did not influence the final cell density achieved in the presence of RCE and actually was slightly stimulatory in its absence. Chondroitin sulphate, in contrast, was found to reduce final cell density in the presence of RCE. The reason for this antiproliferative activity is unclear: possibly, chondroitin sulphate binds or inactivates exogenous growth factors. Interestingly, cell density was not affected as strongly by chondroitin sulphate when RCE was absent. The effect of chondroitin sulphate on endothelial mitosis varies according to the species, model, and growth factor examined. Lin et $a l^{27}$ investigated the effect of the addition of chondroitin sulphate and FGF on damaged pig corneal endothelial of corneas maintained in organ culture. FGFb by itself had no effect. Addition of $1 \%$ chondroitin sulphate resulted in a significantly increased endothelial cell density when compared with controls, although the addition of chondroitin sulphate, FGFb, and $10 \%$ FCS to the corneas had no stimulatory effect on endothelial cell density. Lee et al investigated the effect of EGF and chondroitin sulphate on organ cultured pig corneal endothelium. ${ }^{28}$ Chondroitin sulphate at $25 \mathrm{mg} / \mathrm{ml}$ was found to retard endothelial cell growth. EGF reportedly antagonised the inhibitory effect of chondroitin sulphate, although no statistics were presented in support. The origin of the chondroitin sulphate used may be of importance in trying to reconcile different experimental data. Shark chondroitin sulphate is differently sulphated from chicken or bovine chondroitin sulphate $^{29}$ and it is conceivable that differences in sulphation may be responsible for differences in results, as sulphation has been implicated in growth factor binding to glycosaminoglycans. ${ }^{30}$ Additional sources of variation may relate to the method by which a cell culture is supplemented with chondroitin sulphate and to the final concentration used. Incorporation of chondroitin sulphate into the substrate on which endothelial cells are grown, or addition of low levels $(0.08 \% \mathrm{w} / \mathrm{v}$ final concentration) of this agent to the culture medium, have both been reported to promote endothelial cell proliferation. ${ }^{31}$

It has been suggested that the glycoprotein responsible for contact inhibition has a terminal $\beta$ glycosidically linked galactose that is critical for growth inhibition. ${ }^{32}$ In addition, it has been shown that cell culture in the presence of $\beta$ galactosidase or the lectin Bandeiraea simplicifolia, which cleave or bind terminal galactose residues respectively, increases cell proliferation rates. ${ }^{32} \mathrm{We}$ hypothesised that corneal endothelial cells might be contact inhibited through the same $\beta$ galactosidase sensitive mechanism that operates for other cells such as human fibroblasts. ${ }^{12}$ Treatment with $\beta$ galactosidase did, in fact, increase bovine corneal endothelial cell density to a significant extent compared with untreated controls and we suggest that confluent cultures of corneal endothelial cells may be contact inhibited through a similar $\beta$ galactosidase sensitive receptor ligand system. $\beta$ galactosidase treatment and treatment with RCE were neither synergistic nor additive in our experiments, but the concentration of, and exposure time to, the enzyme were fixed and it may be possible to induce higher endothelial cell densities under differing conditions.

All our experiments were performed in RPMI 1640 medium containing 10\% v/v FCS. Corneas preserved in organ culture systems have generally been incubated in Eagle's minimal essential medium (MEM), supplemented variously with $2 \%, 8335 \%, 3410 \%, 3536$ or $20 \%{ }^{22}$ v/v FCS, while $4^{\circ} \mathrm{C}$ preservation systems have usually been based on MEM, Medium 199 (TC 199), or mixtures of these media. ${ }^{37} 38$ RPMI 1640, a medium developed for the culture of human cells, is quite similar to MEM although the former has additional amino acids and other components not present in the latter and the concentrations of some constituents do vary. RPMI 1640 clearly 
supported growth of bovine corneal endothelial cells in vitro. We chose a moderately high concentration of FCS to maximise cell growth while remaining with the range used by other workers.

In conclusion, our data suggest that the optimal conditions for induction of increased corneal endothelial density are not those that are optimal for the maintenance of a viable cornea during storage. None of the stratagems examined is likely to be of any benefit in $4^{\circ} \mathrm{C}$ storage systems and in particular, none of the purified growth factors tested would appear to be potentially useful supplements for corneal storage media at any temperature. Contact inhibition of corneal endothelial cells may be one explanation for the generally disappointing effects of exogenous growth factors on these cells. However, RCE is an effective ${ }^{18}$ if poorly characterised growth promoting agent known to contain a cocktail of growth factors ${ }^{19}$ and is effective at increasing endothelial cell density to a small but significant extent at $32^{\circ} \mathrm{C}$ after relatively short exposure times. Our data are also consistent with the possibility that it may reduce the contact inhibition normally exhibited by corneal endothelial cells. Furthermore, RCE is effective in serum containing medium and in the presence of the colloidal osmotic agent dextran T-500. Addition of RCE to corneal storage media is clearly unacceptable because of the inherent dangers of transmission of infectious agents. However, investigation of mixtures of defined growth factors may prove a fruitful approach for the future, especially given that we have demonstrated that the final endothelial cell density in a confluent monolayer can be increased by factors capable of overcoming contact inhibition.

We thank Ms Sue Taylor for expert statistical assistance and Dr Monica Berry for helpful advice on corneal endothelial cell culture. This work was supported by the NH\&MRC, Flinders 2000 and the Lions Eye Care and Research Foundation.

2000 and the Lions Eye Care and Research Foundation.
Dr Johnstone is currently affiliated with the Department of Orthopaedic Surgery, Adelaide Women's and Children's Hospital, Adelaide, South Australia, Australia.

1 Hoppenreijs VPT, Pels E, Vrensen GFJM, Treffers WF. Basic fibroblast growth factor stimulates corneal endothelial cell growth and endothelial wound healing of human corneas. Invest Ophthalmol Vis Sci 1994; 35: human $41-44$.

2 Tuft S, Eggli P, Boulton M, Marshall J. Assessment of corneal wound repair in vitro. Curr Eye Res 1989; 8: 713-9.

3 Gospodarowicz D, Mescher AL, Birdwell CR. Stimulation of corneal endothelial cell proliferation in vitro by fibroblast and epidermal growth factors. Exp Eye Res 1977; 25: 75-89.

4 Gospodarowicz D, Greenburg G. The effects of epidermal and fibroblast growth factors on the repair of corneal endothelial wounds in bovine corneas maintained in organ endothelial wounds in bovine corneas main
culture. Exp Eye Res 1979; 28: 147-57.

5 Brazzell RK, Sten ME, Aquavella JU, Beverman RW, Baird L. Human recombinant epidermal growth factor in experimental corneal wound healing. Invest Ophthalmol Vis Sci 1991; 32: 336-40.

6 Chung J-H, Fagerholm P. Treatment of rabbit alkali wounds with human epidermal growth factor. Cornea 1989; 8: 122-8.

7 Couch JM, Cullen P, Casey TA, Fabre JW. Mitotic activity of corneal endothelial cells in organ culture with recombinant human epidermal growth factor. Ophthalmology 1987; 94: $1-6$.

8 Pels E, Schuchard Y. The effects of high molecular weight dextran on the preservation of human corneas. Cornea dextran on the preserv.

9 Whittenberger B, Glaser L. Inhibition of DNA synthesis in cultures of 3T 3 cells by isolated surface membranes. Proc Natl Acad Sci USA 1977; 74: 2251-5.

10 Nakamura T, Yoshimoto K, Nakayama Y, Tomita Y,
Ichihara A. Reciprocal modulation of growth and differentiated functions of mature rat hepatocytes in primary culture by cell-cell contact and cell membranes. Proc Natl Acad Sci USA 1983; 80: 7229-33.

11 Wieser RJ, Heck R, Oesch F. Involvement of plasma membrane glycoproteins in the contact-dependent inhibition of growth of human fibroblasts. Exp Cell Res 1985; 158: 493-9.

12 Wieser RJ, Oesch F. Contact inhibition of growth of human diploid fibroblasts by immobilized plasma membrane glycoproteins. F Cell Biol 1986; 103: 361-7.

13 Wieser RJ, Janik-Schmitt B, Renauer D, Schäfer A, Heck R, Oesch F. Contact-dependent inhibition of growth of normal diploid human fibroblasts by plasma membrane glycoproteins. Biochimie 1988; 70: 1661-71.

14 Keuls $M$. The use of 'studentized range' in connection with an analysis of variance. Euphytica 1952; 1: 112-22.

15 Woost PG, Jumblatt MM, Eiferman RA, Schultz GS. Growth factors and corneal endothelial cells: I. Stimulation of bovine corneal endothelial cell DNA synthesis by defined growth factors. Cornea 1992; 11: 1-10.

16 Schultz G, Cipolla L, Whitehouse A, Eiferman R, Woost P, Jumblatt $M$. Growth factors and corneal endothelial cells: III. Stimulation of adult human corneal endothelial cell mitosis in vitro by defined mitogenic agents. Cornea 1992; 11: $20-7$.

17 Lass JH, Musch DC, Gordon JF, Laing RA. Epidermal growth factor and insulin use in corneal preservation. Results of a multi-center trial. The Corneal Preservation Study Group. Ophthalmology 1994; 101: 352-9.

18 Arruti C, Courtois Y. Monolayer organization by serial cultured bovine corneal endothelial cells; effects of a retina-derived growth promoting activity. Exp Eye Res 1982; 34: 735-47.

19 Baird A, Esch F, Gospodarowicz D, Guillemin R. Retinaeye-derived endothelial cell growth factors: partial molecular characterization and identity with acidic and basic fibroblast growth factors. Biochemistry 1985; 24: 7855-60.

20 Raymond GM, Jumblatt MM, Bartels SP, Neufeld AH. Rabbit corneal endothelial cells in vitro: effects of EGF. Invest Ophthalmol Vis Sci 1986; 27: 474-9.

21 Pesonen K, Viinikka L, Myllyla G, Kiuru J, Perheentupa J. Characterization of material with epidermal growth factor immunoreactivity in human serum and platelets. $₹ \mathrm{Clin}$ immunoreactivity in human serum

22 Sperling $S$. Human corneal endothelium in organ culture. The influence of temperature and medium of incubation. Acta Ophthalmol 1979; 57: 269-76.

23 Van der Want HJL, Pels E, Schuchard Y, Olesen B, Sperling S. Electron microscopy of cultured human corneas: osmotic hydration and the use of the dextran fraction (Dextran T500) in organ culture. Arch Ophthalmol 1983; 101: 1920-6.

24 Kaufman HE, Varnell ED, Kaufman S. Chondroitin sulfate in a new corneal preservation medium. Am $₹$ Ophthalmol 1984; 98: $112-4$.

25 Stein RM, Bourne WM, Campbell RJ. Chondroitin sulphate for corneal preservation at $4^{\circ} \mathrm{C}$, evaluation by electron microscopy. Arch Ophthalmol 1986; 104: 1358-61.

26 Stein RM, Laibson PR. Comparison of chondroitin sulfate to McCarey-Kaufman medium for corneal storage. $A m \mathcal{F}$ Ophthalmol 1987; 104: 490-3.

27 Lin CP, Böhnke M, Draeger J. Effects of fibroblast growth factor and chondroitin sulphate on predamaged corneal endothelium. An organ culture study. Ophthalmic Res 1990; 22: 173-7.

28 Lee HJ, Lin CP, Chen CW. The effects of epidermal growth factor and chondroitin sulfate on the animal corneal endothelial cell culture. Kao Hsiung I Hsueh Ko Hsueh Tsa Chih 1991; 7: 614-21.

29 Caterson B, Mahmoodian F, Sorrell JM, Hardingham TE, Baylis MT, Carney SL, et al. Modulation of native chondroitin sulphate structure in tissue development and in disease. $f$ Cell Sci 1990; 97: 411-7.

30 Ishihara M, Guo Y, Wei Z, Yang Z, Sweidler SJ, Orellana $A$, et al. Regulation of biosynthesis of the basic fibroblast growth factor binding domains of heparan sulfate by heparan sulfate- $\mathrm{N}$-deacetylase $/ \mathrm{N}$-sulfotransferase expression. F Biol Chem 1993; 268: 20091-5.

31 Engelmann K, Böhnke M, Friedl P. Isolation and long-term cultivation of human corneal endothelial cells. Invest Ophthalmol Vis Sci 1988; 29: 1656-62.

32 Wieser RJ, Oesch F. Contact-dependent regulation of growth of diploid human fibroblasts is dependent upon the presence of terminal galactose residues on plasma membrane glycoproteins. Exp Cell Res 1988; 176: 80-6.

33 Easty DL, Carter CA, Lewkowicz-Moss SJ. Corneal cell culture and organ storage. Trans Ophthalmol Soc UK 1986; 105: 385-96.

34 Lindstrom RL, Doughman DJ, Skelnik DL, Mindrup EA. Minnesota system corneal preservation. Br $\mathcal{f}$ Ophthalmol 1986; 70: 47-54.

35 Doughman DJ, Harris JE, Mindrup E, Lindstrom RL. Prolonged donor cornea preservation in organ culture: long-term clinical evaluation. Cornea 1982;1:7-20.

36 Richard NR, Anderson JA, Weiss JL, Binder PS. Air $/$ liquid corneal organ culture: a light microscopic study. Curr Eye Corneal organ culture:

37 McCarey BE, Kaufman HE. Improved corneal storage. Invest Ophthalmol 1974; 13: 165-73.

38 Kaufman HE, Beuerman RW, Steinemann TL, Thompson HW, Varnell ED. Optisol corneal storage medium. Arch Ophthalmol 1991; 109: 864-8. 